\title{
Revista de Estudos da
}

Comunicação

\section{Editorial}

A Revista de Estudos da Comunicação, em sua edição 36, reafirma seu foco na área de Comunicação e Tecnologias, especialmente no que se refere às linhas de pesquisa sobre Cultura e Ambientes Midiáticos e Gestão da Comunicação. As inovações tecnológicas impõem novas práticas e usos comunicacionais, ao mesmo tempo em que os reedita sob novas formas. Este é o caso apresentado no artigo "Espaço público virtualizado: o uso do Facebook nas eleições 2012", que discute o papel da rede social mais utilizada no Brasil atualmente no processo políticoeleitoral. As autoras Karla de Lourdes Ferreira e Maria do Socorro Furtado Veloso apresentam resultado de pesquisa elaborada no Programa de Pós-Graduação em Estudos da Mídia da Universidade Federal do Rio Grande do Norte, que volta a estar em pauta já que se está em ano eleitoral.

Em 2014, também se tem Copa do Mundo no Brasil. Esse é o assunto do segundo artigo desta edição: "Os principais desafios da TV Digital na Copa do Mundo e Olimpíadas", dos autores Alan César Belo Angeluci, Angelo Sottovia Aranha e Danielle Fernandes.

A pesquisa acompanha o cronograma de desligamento dos sinais de TV analógicos previsto para acontecer justamente durante a realização de dois grandes eventos esportivos no Brasil.

Nesta edição, a Revista de Estudos da Comunicação apresenta também o resultado de uma pesquisa que observou como os meios de comunicação retratam a questão das migrações na contemporaneidade. No artigo "MidiaMigra: relato de uma experiência de observação da mídia", os autores Sofia Cavalcanti Zanforlin, Ana Carolina Kalume Maranhão, Maycon Fidalgo e Mariana de Ávila, que integraram a equipe na Universidade Católica de Brasília, buscaram identificar se os discursos criam imagens positivas ou negativas das populações migrantes.

A discussão sobre gênero e mídia está presente no artigo "O lampião da esquina: discussões de gênero e sexualidade no Brasil no final da década de 1970", de Leonardo Schultz e Patrícia Marcondes de Barros. O jornal foi pioneiro em tratar assuntos voltados aos homossexuais em um período de cerceamento da liberdade de expressão, por causa do regime militar de 1964, pro- 
pondo uma "nova visão", formato e estética próprios, negando padrões de objetividade do jornalismo tradicional.

Ainda na abordagem das narrativas jornalísticas, o artigo "Jornalismo literário, humanização e polifonia: perfis da música erudita em piauí", de Mateus Yuri Passos, analisa três reportagens publicadas na revista, a partir dos conceitos de dialogismo, polifonia e discurso não-oficial de Mikhail Bakthin. O autor observa que o jornalismo literário busca vozes e pontos de vista diferenciados, nos quais política e ideologia do cotidiano somam-se ao cenário da música erudita, humanizando os personagens retratados e aproximando o leitor do universo da música erudita.

A forma como a mídia contribui na apropriação da arte e da cultura é trazida também no artigo "Comunicação, arte e cultura: a mediação midiática nos modos de ver e produzir saberes artísticos culturais na cidade Curitiba", por Adalgisa Oliveira. A pesquisa foi realizada a partir da análise de conteúdo do jornal Gazeta do Povo na busca pela compreensão dos processos de significação, de apropriação e assimilação dos saberes culturais.

A utilização de ferramentas midiáticas nas escolas como elemento que favorece a prática da cidadania é abordada no artigo "Comunicação, educação e cidadania: análise do uso de mídias em escolas do Cariri cearense", de Rosane da Silva Nunes. A pesquisa se desenvolve na região do Cariri cearense - municípios do Crato, Juazeiro do Norte e Barbalha, utilizando métodos quanti-qualitativos, envolvendo técnicas de apuração do número de escolas com ações educomunicacionais, aplicação de formulários semiestruturados com vistas a conhecer a estrutura de trabalho nesses projetos, observação direta das atividades educomunicacionais e abordagens interventivas. Boa leitura!

Profa. Dra. Mônica Kaseker Editora-chefe 